\title{
Bilateral acute angle-closure glaucoma as a first presentation of granulomatosis with polyangiitis (Wegener's)
}

\author{
Glaucoma de ângulo fechado bilateral agudo como uma primeira apresentação da granulomatose com \\ poliangeíte (de Wegener)
}

Alper Mete ${ }^{1}$, Sabit Kimyon ${ }^{1}$, Oguzhan Saygilli ${ }^{1}$, Can Pamukcu², Kivanç Güngör ${ }^{1}$

\begin{abstract}
We report a case of bilateral acute angle-closure glaucoma in a patient with undiagnosed granulomatosis with polyangiitis (Wegener's). A 59-year-old man presented with a severe headache, ocular pain, blurred vision, shortness of breath, and mild fever. Clinical examination revealed conjunctival chemosis, corneal edema, and shallow anterior chambers. Closed angles were observed bilaterally on gonioscopy. The patient was treated with intravenous mannitol, oral acetazolamide, and anti-glaucomatous eye drops. Over the following two days, his vision improved and intraocular pressures decreased. Subsequently, laser iridotomies were performed bilaterally and the patient attended consultations with our departments of respiratory medicine, nephrology, and rheumatology and was subsequently diagnosed with granulomatosis with polyangiitis. Bilateral acute angle-closure glaucoma is a very rare ocular manifestation of granulomatosis with polyangiitis. The association of this clinical entity with Wegener's granulomatosis remains unknown.
\end{abstract}

Keywords: Glaucoma, angle-closure/diagnosis; Acute disease/diagnosis; Granulomatosis with polyangiitis/diagnosis; Vasculitis

\begin{abstract}
RESUMO
Relatamos um caso glaucoma bilateral agudo de ângulo fechado em um paciente sem diagnóstico prévio de granulomatose com poliangeíte (Wegener). Um homem de 59 anos apresentou-se com uma forte dor de cabeça, dor nos olhos, visão turva, dificuldade em respirar e febre baixa. Observamos quemose conjuntival, edema da córnea e câmara anterior rasa. A gonioscopia demonstrou ângulos fechados bilateralmente. Ele foi tratado com manitol intravenoso, acetazolamida oral, olho e colírios antiglaucomatosos. Durante os dois dias seguintes a sua visão melhorou e as pressões intra-oculares diminuíram. A seguir, foram realizadas iridotomias a laser bilateralmente e ele foi referido para os departamentos de doenças pulmonares, nefrologia e reumatologia. Ele foi diagnosticado com poliangeíte granulomatosa. Glaucoma bilateral agudo de ângulo fechado é uma entidade clínica muito rara e sua associação com a granulomatose de Wegener é desconhecida e deve acrescentar-se à lista de manifestações oculares de granulomatose com poliangeíte.
\end{abstract}

Descritores: Glaucoma de ângulo fechado/diagnóstico; Doençaaguda/diagnóstico; Granulomatose com poliangíte/diagnóstico; Vasculite

\section{INTRODUCTION}

Granulomatosis with polyangiitis (Wegener's) predominantly affects the upper and lower respiratory tracts, lungs, and kidneys and represents a rare multisystem necrotizing granulomatous vasculitis of small-sized vessels. Central nervous system, cutaneous, heart, gastrointestinal tract, orbital, and ocular involvement may also be observed ${ }^{(1)}$. Ocular or orbital involvement in granulomatosis with polyangiitis is reportedly occurs in $20-50 \%$ of patients ${ }^{(2,3)}$.

Bilateral acute angle-closure (AAC) glaucoma is a very rare clinical entity that is generally caused by the use of various topical or systemic medications, many of which are known to cause pupillary dilatation, emotional stress, dim illumination, surgical anesthesia, viral infections, systemic vasculitis, and subarachnoid hemorrhage ${ }^{(4-7)}$. To our knowledge, this is the first reported case of granulomatosis with polyangiitis presenting with bilateral acute angle-closure glaucoma.

\section{CASE REPORT}

A 59-year-old Caucasian man presented to a local ophthalmologist with acute bilateral onset of ocular pain, blurred vision, and a severe headache. He was diagnosed with bilateral AAC glaucoma and immediately referred to the Ophthalmology Department, Gaziantep University for further evaluation and treatment.

On initial examination, his best-corrected visual acuity (BCVA) was 20/200 in both eyes (OU). IOPs were measured using an applanation tonometer and recorded as $43 \mathrm{mmHg}$ and $47 \mathrm{mmHg}$ in the right and left eye, respectively. On slit-lamp examination we observed bilateral conjunctival chemosis, mild corneal edema, shallow anterior chambers, and immature senile cataracts. On gonioscopy, we observed angle closure in the superior and lateral quadrants (Shaffer Classification, Grade 0), and Grade 1 angle closure in the inferior and medial quadrants. There was no evidence of previous angle closure glaucoma, such as iris atrophy or glaucomflecken. He had no previous glaucoma-related medical history. We initially planned treatment with timolol maleate, $0.5 \%$ twice daily; brimonidine, $0.15 \%$ twice daily; pilocarpine, $1 \%$ four times daily; oral acetazolamide, $250 \mathrm{mg}$ four times daily; and $350 \mathrm{ml}$ mannitol, 20\% intravenously. Six hours later, IOPs dropped to $28 \mathrm{mmHg}$ bilaterally. The following day, we continued topical anti-glaucomatous medication and oral acetazolamide. His BCVA improved to 20/30 and 20/40 in the right and left eye, respectively. His IOP dropped to $19 \mathrm{mmHg}$ and $20 \mathrm{mmHg}$ in the right and left eyes, respectively. On slit-lamp examination, we observed resolution
Submitted for publication: September 22, 2015

Accepted for publication: December 2, 2015

Department of Ophthalmology, School of Medicine, Gaziantep University, Gaziantep, Turkey.

2 Department of Ophthalmology, Hatem Private Hospital, Gaziantep, Turkey.
Funding: No specific financial support was available for this study.

Disclosure of potential conflicts of interest: None of the authors have any potential conflict of interest to disclose.

Corresponding author: Alper Mete. Gaziantep University. School of Medicine - Department of Ophthalmology - Gaziantep 27310 - Turkey - E-mail: dralpermete@hotmail.com 
of the mild corneal edema, reduction in conjuctival chemosis, and improved anterior chamber depth which continued to be shallow peripherally (Figure 1). Undilated fundus examination demonstrated normal optic discs and maculae in both eyes. Subsequently, YAG laser iridotomies were performed 36 hours after the initial examination. On the third day, IOPs were $11 \mathrm{mmHg}$ in the right eye and $13 \mathrm{mmHg}$ in the left eye with topical and oral anti-glaucomatous medication. Therefore, oral acetazolamide was stopped at this time.

The patient reported a one-week duration of shortness of breath and mild fever at the initial presentation. We therefore arranged a consultation with our department of respiratory medicine on the first day of hospitalization. Laboratory examinations and radiological evaluations were planned by the same department. Serological examination demonstrated an elevated erythrocyte sedimentation rate, proteinuria, and elevated levels of C-reactive protein, urea, and creatinine. Chest radiography and computed tomography $(\mathrm{CT})$ revealed ground glass opacities with nodular consolidation in the right upper lobe. Enlarged bilateral axillary, paratracheal, and carinal lymph nodes were also noted (Figure 2 A, B). Subsequently, he was evaluated by our departments of rheumatology and nephrology. Abdominal CT and ultrasonography revealed bilateral cysts within the kidney parenchyma. Pathological examination of a kidney biopsy specimen was reported as consistent with focal and segmental glomerulosclerosis (FSGS) with chronic tubulointerstitial changes. Additional laboratory evaluations revealed the presence of autoantibodies to neutrophil cytoplasmic components (cytoplasmic anti-neutrophil cytoplasmic antibodies, C-ANCA) with proteinase-3 (PR3) specificity. Granulomatosis with polyangiitis (Wegener's) was diagnosed accordingly and treatment with cyclophosphamide and prednisolone was initiated.

The patient attended a follow-up visit one week later and reported complete resolution of his ocular symptoms. His BCVA had improved
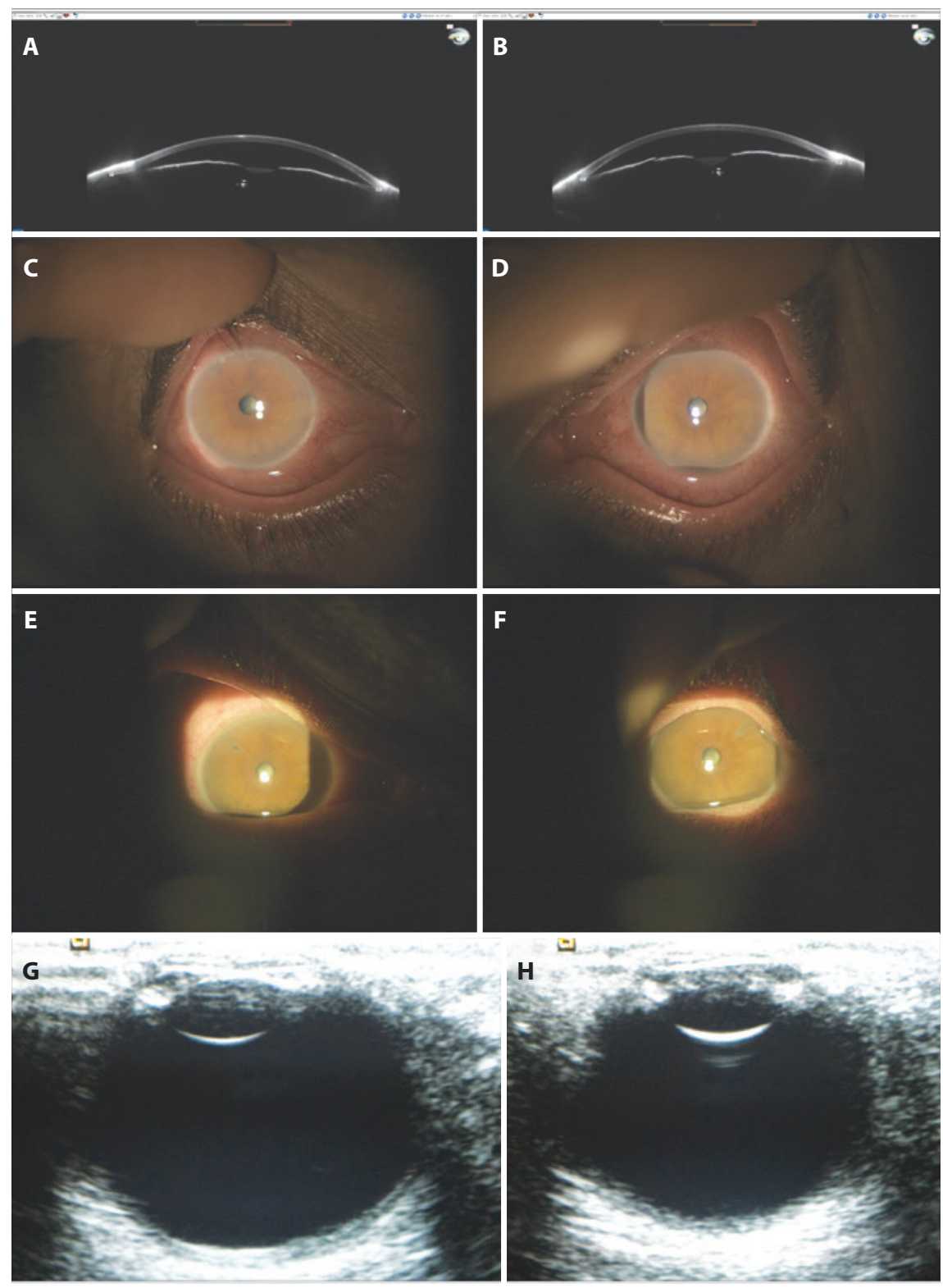

Figure 1. A, B) Sirius topography revealed narrow angles in both eyes on the second day. C, D) Slit-lamp examination of both eyes on the second day. E, F) Slit-lamp examination of both eyes following laser iridotomy. G, H) B-scan ultrasonography of both eyes on the second day. 

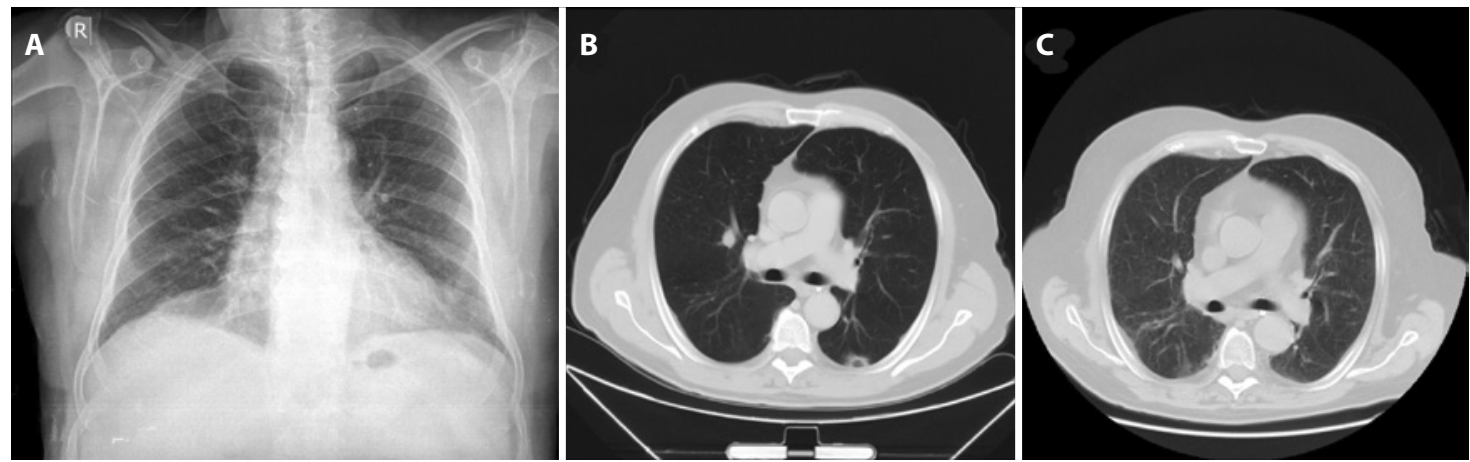

Figure 2. A) Chest radiography revealed bilateral opacities consistent with focal consolidation. B) Chest CT demonstrated ground glass opacities with focal regions of consolidation in the right upper lobe. C) Chest CT at 3 months after systemic cyclophosphamide and prednisolone therapy demonstrated complete resolution of nodular opacities in the right upper lobe.

to $20 / 20$ and $20 / 25$ in the right and left eye, respectively. IOPs were $15 \mathrm{mmHg}$ in the right eye and $16 \mathrm{mmHg}$ in the left eye. Openings created by laser iridotomy were seen to be patent. Gonioscopy revealed angles open to the scleral spur bilaterally. All systemic symptoms continued to gradually improve with systemic treatment (Figure 2 C).

\section{DISCUSSION}

Granulomatosis with polyangiitis, formerly known as Wegener's granulomatosis, commonly involves the upper and lower respiratory tracts and kidneys. Ocular or orbital manifestations are present in approximately one-tenth of patients with granulomatosis with polyangiitis ${ }^{(8)}$. Ocular involvement can range from mild conjunctivitis and episcleritis to more severe inflammation with peripheral ulserative keratitis, scleritis, uveitis, and retinal vasculitis. Orbital involvement may cause proptosis, diplopia, restrictive myopathy, and compressive optic neuropathy, as a consequence of orbital inflammation ${ }^{(8)}$. Ocular or orbital manifestations may result from a variety of pathologies, including focal vasculitis of small-sized vessels, granulomatous inflammation, vascular thrombosis, hemorrhage, or as a consequence of chronic inflammation or ischemia ${ }^{(9)}$. AAC glaucoma has been previously reported to be associated with other vasculitides ${ }^{(4-6)}$. The exact mechanisms underlying the association between AAC glaucoma and systemic vasculitis are yet to be elucidated. Choroidal ischemia secondary to vasculitis may cause choroidal thickening of an already narrow angle, which may then precipitate an acute episode of glaucoma. Previous studies have reported that a 20\% increase in choroidal thickness is sufficient to result in a forward shift of the iris against the cornea and acute development of glaucoma ${ }^{(10)}$. Alternatively, iris sphincter ischemia secondary to vasculitis, AAC glaucoma, or increased sympathetic output due to pain related to vasculitis may cause mydriasis and precipitate acute glaucoma ${ }^{(6)}$. In the present case, we did not observe choroidal thickening on B-Scan ultrasonography or fundus examination. Therefore, we believe AAC glaucoma in our patient was most likely due to the development of mydriasis.

An accurate diagnosis of granulomatosis with polyangiitis is dependent on comprehensive clinical examinations and supporting pathology evaluations. Early diagnosis and treatment of granulomatosis with polyangiitis may prevent the development of serious associated complications. To the best of our knowledge, this is the first report of bilateral AAC glaucoma as the initial presenting symptom of granulomatosis with polyangiitis. The findings in the present case demonstrate AAC glaucoma as a rare but significant manifestation of granulomatosis with polyangiitis.

\section{REFERENCES}

1. Newman NJ, Slamovits TL, Friedland S, Wilson WB. Neuro-ophthalmic manifestations of meningocerebral inflammation from the limited form of Wegener's granulomatosis. Am J Ophthalmol. 1995;120(5):613-21.

2. Bullen CL, Liesegang TJ, McDonald TJ, DeRemee RA. Ocular complications of Wegener's granulomatosis. Ophthalmology. 1983;90(3):279-90.

3. Haynes BF, Fishman ML, Fauci AS, Wolff SM. The ocular manifestations of Wegener's granulomatosis. Fifteen years experience and review of the literature. Am J Med. 1977;63(1):131-41

4. Hunter TG, Chong GT, Asrani S, Allingham RR, Blumberg DM. Simultaneous bilateral angle closure glaucoma in a patient with giant cell arteritis. J Glaucoma. 2010;19(2): 149-50.

5. Yao J, Chen Y, Shao T, Ling Z, Wang W, Qian S. Bilateral acute angle closure glaucoma as a presentation of vogt-koyanagi-harada syndrome in four chinese patients: a small case series. Ocul Immunol Inflamm. 2013;21(4):286-91.

6. Kranemann CF, Buys YM. Acute angle-closure glaucoma in giant cell arteritis. Can J Ophthalmol. 1997;32(6):389-91.

7. Ceruti P, Morbio R, Marraffa M, Marchini G. Simultaneous bilateral acute angle-closure glaucoma in a patient with subarachnoid hemorrhage. J Glaucoma. 2008;17(1):62-6.

8. Perez VL, Chavala SH, Ahmed M, Chu D, Zafirakis P, Baltatzis S et al. Ocular manifestations and concepts of systemic vasculitides. Surv Ophthalmol. 2004;49(4):399-418.

9. Pakrou N, Selva D, Leibovitch I. Wegener's granulomatosis: ophthalmic manifestations and management. Semin Arthritis Rheum. 2006;35(5):284-92.

10. Quigley HA, Friedman DS, Congdon NG. Possible mechanisms of primary angle closure and malignant glaucoma. J Glaucoma. 2003;12(2):167-80. 